Bul. Agrohorti 6 (2) : 258 - 269 (2018)

\title{
Respon Genotipe Tanaman Kedelai (Glycine max L. Merrill) dari Berbagai Negara Terhadap Kondisi Lingkungan Tumbuh Kebun IPB Sawah Baru
}

\section{Response of Soybean Genotypes (Glycine max L. Merrill) from Various Countries to Environmental Condition at The Experimental Field IPB Sawah Baru}

\author{
Dewi Valentina Butar Butar dan Iskandar Lubis*
}

Departemen Agronomi dan Hortikultura, Fakultas Pertanian, Institut Pertanian Bogor (Bogor Agroculture University) Jl. Meranti, Kampus IPB Dramaga, Bogor 16680, Indonesia

Telp.\&Fax.62-251-8629353e-mail agronipb@indo.net.id

*Penulis untuk korespondensi : iskandarlbs@yahoo.com

Disetujui 14 Mei 2018 / Published online 21 Mei 2018

\begin{abstract}
This research aims to study the response of growth and production of 130 soybean genotypes from various countries to the condition of IPB Sawah Baru Station. The experimental design used was augmented design in randomized complete design (RCB). Soybean seeds that were used as check varieties namely: Tanggamus, Anjasmoro, Argo Mulyo, Wilis and Tachinagaha (Japan soybean variety) consist of 5 replicates so there were 150 units of the experiment. The results indicated that the genotype GmWMC192 from Nepal has high result and adaptable at the field IPB Sawah Baru. It is seen from the percentage of plants survived, plant height, the number of node, number of pods per plant, and high percentage of full seeds. In addition, genotypes GmWMC042*2 and GmWMC019 from North Korea and China was very fast growth (66 days) and also adaptable at the field IPB Sawah Baru. Both the genotype can be used as a source of repair genes in soybean growth duration.
\end{abstract}

Keywords: full seeds, adaptability, number of node, augmented design

\begin{abstract}
ABSTRAK
Penelitian ini bertujuan mempelajari respon pertumbuhan dan produksi 130 genotipe kedelai dari berbagai negara terhadap lingkungan tumbuh Kebun Percobaan IPB Sawah Baru. Percobaan ini disusun dengan rancangan augmented dalam rancangan acak lengkap (RAL). Benih kedelai yang digunakan sebagai pembanding (kontrol) adalah kedelai varietas Tanggamus, Anjasmoro, Argo Mulyo, Wilis dan Tachinagaha (varietas Jepang) yang terdiri dari 5 ulangan sehingga terdapat 150 satuan percobaan. Hasil penelitian menunjukkan bahwa genotipe GmWMC192 yang berasal dari Nepal berdaya hasil tinggi dan beradaptasi baik pada lahan Kebun Percobaan IPB Sawah Baru. Hal ini dilihat dari persentase daya tumbuh di lapangan, tinggi tanaman, jumlah buku, jumlah polong per tanaman, dan persentase biji penuh/sempurna yang tinggi. Selain itu, genotipe GmWMC019 dan GmWMC042*2 yang berasal dari Korea Utara dan Republik Rakyat Cina berumur sangat genjah (66 hari) serta beradaptasi baik pada lahan Kebun Percobaan IPB Sawah baru. Kedua genotipe tersebut dapat digunakan sebagai sumber gen dalam perbaikan umur panen kedelai.
\end{abstract}

Kata kunci: biji penuh, daya adaptasi, jumlah buku, rancangan augmented 


\section{PENDAHULUAN}

Kedelai (Glycine max L. Merril) termasuk komoditas tanaman pangan terpenting setelah padi dan jagung. Kedelai merupakan salah satu sumber protein yang paling banyak dikonsumsi masyarakat Indonesia karena harganya yang relatif terjangkau. Kebutuhan kedelai nasional akan terus meningkat seiring dengan meningkatnya permintaan sebagai bahan baku industri pangan. Konsumsi kedelai pada tahun 2013 sebesar 2.5 juta ton (BAPPENAS 2014) sedangkan produksi kedelai nasional tahun 2013 sebesar 807.57 ribu ton biji kering atau turun 4.22 $\%$ dibandingkan tahun 2012 (BPS 2013a). Peningkatan konsumsi kedelai nasional tersebut sangat dipengaruhi oleh peningkatan jumlah penduduk Indonesia. Jumlah penduduk Indonesia pada tahun 2013 sebesar 242.013 juta jiwa (BPS 2013b). Oleh karena itu, masalah konsumsi kedelai yang terus meningkat tersebut membutuhkan adanya upaya untuk meningkatkan produktivitas nasional.

Peningkatan produktivitas kedelai nasional saat ini dihadapkan pada berbagai tantangan, salah satunya adalah perubahan iklim. Pemanasan global mengakibatkan terjadinya peningkatan suhu di sentra-sentra produksi kedelai. Sumarno dan Ahmad (2007a) menyatakan suhu yang tinggi mengakibatkan terjadinya aborsi polong pada tanaman kedelai sehingga berpengaruh terhadap penurunan pertumbuhan dan produktivitas tanaman kedelai. Oleh karena itu, untuk mengatasi permasalahan suhu tinggi tersebut diperlukan varietas kedelai yang tahan terhadap suhu tinggi.

Pemuliaan tanaman terlebih dahulu melakukan uji daya adaptasi sebelum menghasilkan atau mengembangkan suatu varietas. Percobaan uji daya adaptasi merupakan salah satu cara untuk mengkaji respon genotipe terhadap lingkungan tumbuhnya. Kajian ini penting digunakan untuk menduga dan menyeleksi genotipe-genotipe yang beradaptasi pada suatu lingkungan spesifik atau berpenampilan stabil. Rasyad dan Idwar (2010) menyatakan galur atau varietas yang stabil umumnya mempunyai keragaman yang kecil jika ditanam pada kondisi lingkungan yang berbeda atau memiliki keragaan yang tetap pada berbagai lingkungan. Oleh karena itu, varietas yang stabil akan memberikan tanggap hasil yang relatif sama meskipun lingkungannya berbeda. Kestabilan suatu varietas bukan hanya ditunjukkan oleh hasilnya saja tetapi juga diperlihatkan oleh kestabilan sifat-sifat agronomis lain seperti komponen hasilnya. Hasil uji daya adaptasi tersebut diharapkan dapat memperoleh genotipe dengan adaptabilitas yang baik sehingga selanjutnya dapat dikembangkan lebih lanjut.

Varietas kedelai dari wilayah subtropis yang sesuai untuk panjang hari 14-16 jam apabila ditanam di Indonesia yang panjang harinya 12 jam maka akan mempercepat pembungaan pada umur 20-22 hari walaupun batang tanaman masih pendek, dan tanaman sudah berbunga. Sedangkan varietas asal subtropis di tempat aslinya, berbunga pada umur tanaman sekitar 50 hari saat batang kedelai sudah tumbuh setinggi 60-70 cm (Sumarno dan Ahmad 2007b). Oleh karena itu, penelitian ini bertujuan mempelajari pengaruh perbedaan lingkungan tumbuh genotipe kedelai terutama akibat suhu terhadap pertumbuhan dan produksinya. Genotipe yang memiliki karakter unggul berdasarkan hasil uji daya adaptasi tersebut, selanjutnya dapat diusulkan kepada pemulia tanaman untuk dikembangkan sebagai sumber gen dalam melakukan persilangan tanaman untuk merakit varietas unggul nasional.

\section{BAHAN DAN METODE}

Penelitian berlangsung pada tanggal 17 Februari sampai 30 Mei 2014 di Kebun Percobaan IPB Sawah Baru, Dramaga, Bogor.

Bahan yang digunakan adalah 130 genotipe kedelai dari berbagai negara, pupuk $50 \mathrm{~kg} \mathrm{ha}^{-1}$ Urea, $150 \mathrm{~kg} \mathrm{ha}^{-1} \mathrm{SP}-36$, dan $100 \mathrm{~kg} \mathrm{ha}^{-1} \mathrm{KCl}$, legin serta karbofuran. Identitas genotipe kedelai yang digunakan pada percobaan terdapat pada Lampiran 1. Alat yang digunakan adalah cangkul, sprayer, meteran, timbangan, alat penanda percobaan (label), ember, oven, kamera, moisture tester.

Penelitian ini disusun dengan rancangan augmented dalam rancangan acak lengkap (RAL) dengan genotipe kedelai sebagai perlakuan $(\mathrm{P})$ tunggal. Benih kedelai yang digunakan sebagai pembanding (kontrol) adalah kedelai varietas Tanggamus, Anjasmoro, Argo Mulyo, Wilis dan Tachinagaha (varietas Jepang) terdiri dari 5 ulangan sehingga terdapat 150 satuan percobaan. Setiap petak percobaan berukuran $5 \mathrm{~m} \times 2 \mathrm{~m}$ dengan jumlah 10 tanaman per baris.

Persiapan dan pengolahan tanah dilakukan dua minggu sebelum penanaman untuk membersihkan gulma. Masing-masing petak percobaan dibuat dengan ukuran $5 \mathrm{~m} \times 2 \mathrm{~m}$ dan saluran drainase atau selokan dengan lebar 0.5 meter untuk menghindari genangan air.

Penanaman dilakukan dengan ditugal sebanyak 2 butir/lubang dengan jarak tanam 50 $\mathrm{cm} \times 20 \mathrm{~cm}$. Benih direndam dengan legin selama 4-5 menit dan saat penanaman diberikan 
karbofuran 5-7 butir pada masing-masing lubang tanam. Penyulaman dilakukan dengan mencabut tanaman kedelai yang tumbuh pada lubang tanam secara hati-hati agar akar utama tidak terputus dan dilakukan pada sore hari.

Pemupukan dilakukan pada saat penanaman dengan cara dialur di samping barisan tanaman. Dosis pupuk yang digunakan adalah $50 \mathrm{~kg} / \mathrm{ha}$ urea, $150 \mathrm{~kg} / \mathrm{ha}$ SP-36 dan $100 \mathrm{~kg} / \mathrm{ha} \mathrm{KCl}$.

Pengendalian gulma dilakukan secara manual sebelum penanaman dan setelah penanaman setiap minggu. Pengendalian hama dan penyakit secara kimiawi dilakukan apabila diperlukan.

Pemanenan dilakukan apabila $95 \%$ dari populasi polong per tanaman contoh telah berwarna kuning kecoklatan (100-110 HST) dan daun gugur. Waktu panen berbeda-beda tergantung pada masing-masing genotipe.

Data yang diperoleh dianalisis melalui uji $\mathrm{F}$ pada selang kepercayaan 95\%. Jika terdapat pengaruh nyata maka akan dilanjutkan dengan uji BNT.

Pengamatan dilakukan terhadap 3 tanaman contoh untuk setiap genotipe kedelai. Pengamatan dimulai pada satu minggu setelah tanam (MST) dengan menghitung daya tumbuh benih di lapangan. Peubah tanaman yang diamati di lapangan terdiri atas :

1. Persentase tanaman tumbuh : diamati setelah 2 MST,

2. Tinggi tanaman $(\mathrm{cm})$ : diukur dari pangkal batang hingga bagian ujung (titik tumbuh) batang utama pada saat fase R1 dan R7,

3. Umur berbunga (hari) : diamati saat $50 \%$ jumlah populasi berbunga,

4. Waktu muncul polong (hari) : diamati pada saat terdapat satu atau lebih polong sepanjang $5 \mathrm{~mm}$ pada batang utama (fase R3),
5. Jumlah buku per tanaman : diamati pada saat fase R1 dan R3,

6. Warna bunga : diamati pada saat fase R1,

7. Waktu perubahan polong menjadi matang (hari): diamati pada fase R7,

8. Waktu panen (hari) : diamati apabila $95 \%$ polong telah matang (kuning kecoklatan atau kehitaman),

9. Bobot kering tajuk (g) : Bagian tajuk tanaman dipisahkan dari akar dengan cara memotong pada bagian pangkal batang lalu tajuk tersebut dioven pada suhu $80{ }^{\circ} \mathrm{C}$ selama 3 hari (kadar air 0\%),

10. Jumlah polong per tanaman: diamati pada saat setelah panen,

11. Jumlah cabang per tanaman : diamati pada saat fase R8,

12. Warna biji : diamati pada saat setelah panen,

13. Bobot 100 biji (g) : adalah bobot biji yang dihasilkan setelah dipanen dan dijemur di bawah sinar matahari selama 3-5 hari (kadar air 14\%),

14. Persentase kondisi biji yaitu menghitung benih penuh/sempurna, keriput, rusak dan unfertile,

15. Ukuran biji : diamati setelah menimbang bobot 100 biji,

\section{HASIL DAN PEMBAHASAN}

\section{Kondisi Umum}

Kondisi iklim rata-rata per bulan di wilayah Dramaga pada bulan Februari sampai Mei 2014 adalah sebagai berikut; curah hujan rata-rata sebesar $424 \mathrm{~mm}$, suhu rata-rata sebesar $25.3^{\circ} \mathrm{C}$ dan kelembaban rata-rata sebesar $88 \%$ (BMKG 2014). Berikut data hasil analisis sifat kimia dan fisik tanah kebun percobaan IPB Sawah Baru yang disajikan pada Tabel 1.

Tabel 1 Hasil analisis sifat kimia dan fisik tanah kebun percobaan IPB Sawah Baru

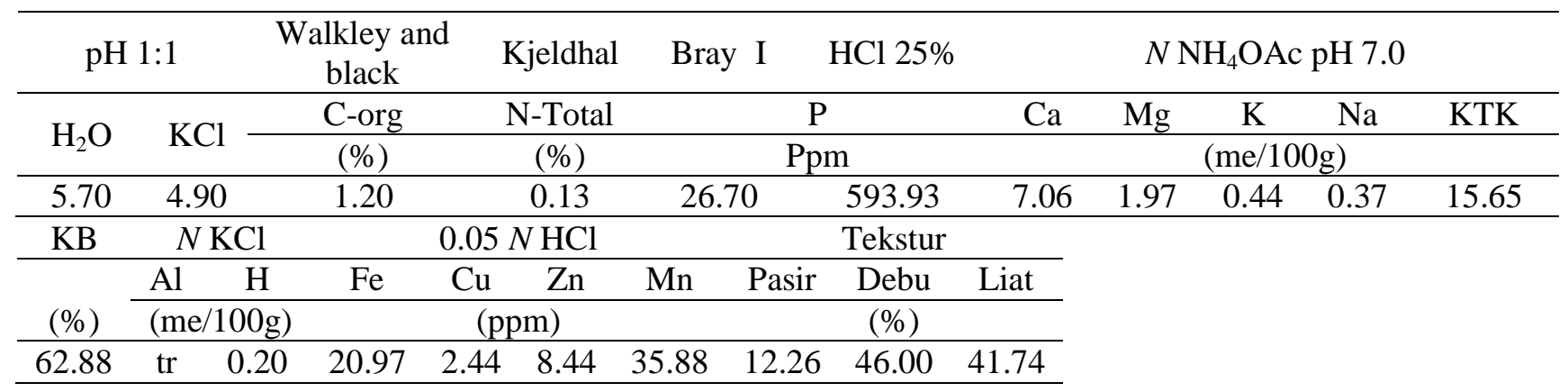

Sumber : Laboratorium Departemen ITSL IPB 2014 
Kondisi optimum untuk pertanaman kedelai adalah; curah hujan berkisar 120-135 mm/bulan, suhu rata-rata $22-27{ }^{\circ} \mathrm{C}$, kelembaban udara yang optimal bagi tanaman kedelai berkisar antara 7090\% selama periode tanaman tumbuh hingga stadia pengisian polong dan kelembaban udara rendah antara 60-75\%. Kriteria kesesuaian agroklimat untuk pertanaman kedelai adalah $\mathrm{pH}$ 6.0-6.5, unsur $\mathrm{K}$ sedang-tinggi, $\mathrm{Ca}$ dan $\mathrm{Mg}$ sedang, serta kejenuhan liat sekitar 36-43 (Sumarno dan Manshuri 2007). Berdasarkan kriteria penilaian sifat kimia tanah menurut Hardjowigeno (1995), maka data hasil analisis sifat kimia tanah kebun percobaan IPB Sawah Baru pada Tabel 1 termasuk kriteria rendahsedang dengan tingkat keasamaan tanah $(\mathrm{pH})$ agak masam. Oleh karena itu, lahan percobaan tersebut layak digunakan untuk penelitian budidaya kedelai.

Pertumbuhan dan perkembangan tanaman selama penelitian mengalami gangguan yang disebabkan oleh hama dan penyakit yang berbeda setiap fase pertumbuhannya. Hama yang menyerang pada saat tanaman berkecambah adalah lalat bibit kedelai (Ophiomyia phaseoli) sehingga menyebabkan tanaman layu dan akhirnya mati. Hama dan penyakit yang menyerang tanaman pada saat fase R1 adalah ulat penggulung daun (Lamprosema indicata) sehingga menyebabkan daun berlubang-lubang dan penyakit rebah semai sehingga tanaman mengering. Hama yang menyerang tanaman pada saat fase R3 adalah ulat penggulung daun (Lamprosema indicata) dan kepik polong (Riptortus linearis) sehingga menyebabkan pertumbuhan polong dan biji kempes kemudian gugur. Hama yang menyerang tanaman pada saat fase R7 tidak berbeda dengan fase R3 tetapi terdapat penyakit karat daun (Phakopsora pachyrhizi) yang menyerang tanaman genotipe GmWMC171 sehingga menyebabkan tanaman menjadi rusak. Gulma dominan yang ada di lapangan adalah gulma dari golongan rumput.

\section{Keragaan Karakter Agronomi dan Hasil Genotipe-Genotipe Kedelai}

Hasil rekapitulasi sidik ragam pada Tabel 2 menunjukkan bahwa genotipe berpengaruh nyata pada peubah pengamatan umur dan tinggi tanaman pada setiap fase, jumlah cabang, jumlah buku pada saat fase R8 dan bobot kering tajuk. Hal ini menunjukkan bahwa terdapat keragaman pada antar genotipe dan varietas pembanding (kontrol). Peubah pengamatan seperti kadar air, bobot 100 biji, persentase biji penuh/sempurna, biji rusak dan biji unfertile berpengaruh tidak nyata pada antar genotipe dan varietas pembanding (kontrol) sehingga peubah tersebut tidak perlu dilakukan uji lanjut BNT.

Tabel 2 Rekapitulasi hasil sidik ragam berbagai karakter genotipe tanaman kedelai yang diamati

\begin{tabular}{|c|c|c|c|c|}
\hline Parameter & $\mathrm{G}$ & $\mathrm{K}$ & $\mathrm{G}^{*} \mathrm{~K}$ & $\mathrm{KK}(\%)$ \\
\hline Umur tanaman pada fase $\mathrm{R} 1$ & $* *$ & $* *$ & $* *$ & 8.56 \\
\hline Umur tanaman pada fase R3 & $* *$ & $* *$ & $* *$ & 5.96 \\
\hline Umur tanaman pada fase R7 & $* *$ & $* *$ & $* *$ & 2.27 \\
\hline Umur tanaman pada fase $\mathrm{R} 8$ & $* *$ & $* *$ & $* *$ & 2.75 \\
\hline Tinggi tanaman pada saat fase $\mathrm{R} 1$ & $* *$ & $* *$ & $* *$ & 16.72 \\
\hline Tinggi tanaman pada saat fase $\mathrm{R} 7$ & $* *$ & $* *$ & $* *$ & 11.86 \\
\hline Jumlah buku pada saat fase R1 & tn & $* *$ & $*$ & a) 20.03 \\
\hline Jumlah buku pada saat fase R8 & $* *$ & $* *$ & $* *$ & 14.96 \\
\hline Jumlah cabang & $* *$ & $* *$ & $* *$ & 14.98 \\
\hline Bobot kering tajuk & $* *$ & $* *$ & $* *$ & 6.24 \\
\hline Bobot 100 biji & $* *$ & $* *$ & tn & 10.61 \\
\hline Jumlah polong & tn & $*$ & tn & a) 20.28 \\
\hline Persentase biji penuh/sempurna & tn & tn & tn & a) 26.49 \\
\hline Persentase biji keriput & $* *$ & tn & $* *$ & a) 21.96 \\
\hline Persentase biji rusak & tn & tn & tn & a) 28.02 \\
\hline Persentase biji unfertile & tn & tn & tn & b) 23.95 \\
\hline
\end{tabular}

Keterangan : $* *=$ berbeda nyata pada taraf uji $1 \%, *$ = berbeda nyata pada taraf uji $5 \%$, $\mathrm{tn}=$ tidak berbeda nyata, $\mathrm{G}=\mathrm{Genotipe}, \mathrm{K}=$ Kontrol (varietas pembanding), $\mathrm{G} * \mathrm{~V}=$ Interaksi, $a)=$ data ditransformasikan dengan $\log (\mathrm{x}+2), \mathrm{b})=$ data ditransformasikan dengan $\log (\mathrm{x}+3)$.

\section{Persentase Tumbuh}

Pengamatan terhadap persentase daya tumbuh benih di lapangan dilakukan pada 2 MST. Persentase daya tumbuh benih di lapangan disajikan pada Tabel 3 dengan memberikan keterangan nomor yang dijelaskan pada Lampiran 1. Dapat dilihat pada Tabel 3 bahwa ada 94 genotipe yang memiliki persentase tumbuh yang tinggi yaitu diatas $80 \%$ dan 20 genotipe yang memiliki persentase tumbuh yang rendah yaitu 
dibawah 50\%. Anjasmoro dan Pangrango dengan kode nomor 106 dan 130 memiliki persentase tumbuh yang rendah meskipun tergolong varietas unggul nasional. Hal ini disebabkan karena benih yang digunakan memiliki viabilitas rendah akibat umur simpan benih yang lama. Kartahadimaja et al. (2013) menyatakan bahwa gejala turunnya viabilitas benih akibat penyimpanan pada periode 4 tahun setelah diuji di laboratorium dan di lapangan terjadi karena benih tetap berkecambah, tetapi tidak normal, atau karena benih tidak tumbuh sama sekali atau karena benih sudah mati. Hal ini mengindikasikan bahwa umur simpan benih yang lama maka akan mempengaruhi daya berkecambah benih sehingga persentase tumbuh benih di lapangan menjadi rendah meskipun benih tersebut tergolong varietas kedelai nasional.

Tabel 3 Persentase daya tumbuh dari 125 genotipe kedelai yang diuji dan kelima varietas pembanding

\begin{tabular}{|c|c|c|c|c|}
\hline \multicolumn{5}{|c|}{ Daya Tumbuh (\%) } \\
\hline$(90-100)$ & 80 & $(70-50)$ & $(40-20)$ & 0 \\
\hline $105,129,2,3,4,5,7,9,10,11,12$, & $8,107,13,14$ & $6,26,44,51$, & $24,28,29$ & $27,31,54,61$ \\
\hline $16,17,18,19,21,25,32,35,36,37$ & $15,20,41,42$, & $59,65,81$ & $30,55,70$ & $70,116,117$ \\
\hline $38,43,45,46,47,52,53,56,57,58$, & $49,63,64,71$ & $85,86,112$ & $76,80,106$ & \\
\hline $59,60,62,66,67,68,69,72,73,74$ & 108,120 & & 130 & \\
\hline $75,77,78,82,83,87,88,89,90,91$ & & & & \\
\hline $91,92,93,94,95,96,97,98,99,100$ & & & & \\
\hline $101,102,103,104,109,110,111$, & & & & \\
\hline $113,118,119,121,122,123,124$ & & & & \\
\hline $124,125,126,127,128$ & & & & \\
\hline
\end{tabular}

Tabel 3 menunjukkan bahwa genotipe dengan nomor 27, 31, 54, 61, 70, 116, dan 117 merupakan genotipe yang paling tidak adaptif karena tidak ada tanaman yang hidup di lapangan. Beberapa faktor penyebab hal tersebut adalah rendahnya viabilitas benih, benih yang doman, adanya perbedaan lingkungan tumbuh asalnya terutama akibat suhu, kelembaban udara, dan intensitas cahaya matahari serta serangan hama dan penyakit. Beberapa genotipe kedelai dari wilayah subtropis yang memiliki persentase tumbuh rendah $(<50 \%)$ seperti genotipe dengan nomor 27, 29, 30, 55, dan 61 yang berasal dari Korea, genotipe dengan nomor 28, 31, dan 54 yang berasal dari Republik Rakyat Cina (RRC), genotipe dengan nomor 70 dan 80 yang berasal dari Pakistan dan Nepal. Genotipe dari wilayah subtropis tersebut memiliki persentase tumbuh yang rendah diduga akibat berbedanya iklim di lingkungan tumbuh percobaan dengan iklim negara asal. Genotipe dengan nomor 76 yang berasal dari Thailand juga memiliki persentase tumbuh yang rendah meskipun berasal dari wilayah tropis, diduga diakibatkan rendahnya viabilitas benih sehingga daya berkecambah benih di lapangan rendah.

\section{Umur Tanaman pada Saat Fase R1, R3, R7, dan $R 8$}

Pengamatan umur tanaman dilakukan pada fase-fase tertentu yaitu pada saat tanaman $50 \%$ berbunga (R1), waktu munculnya polong (R3), waktu perubahan warna polong menjadi kuning, cokelat, dan matang (R7), dan umur panen (R8). Data hasil pengamatan umur tanaman pada saat fase R1, R3, R7, dan R8 disajikan pada Tabel 4. Data yang disajikan merupakan genotipe yang memiliki umur paling cepat dan paling lama setiap fasenya dibandingkan varietas pembanding dan genotipe yang ditampilkan adalah genotipe yang didiskusikan. Dapat dilihat pada Tabel 4 bahwa GmWMC019 yang berasal dari Korea Utara dan GmWMC042*2 yang berasal dari RRC merupakan genotipe yang paling cepat mengalami fase R1, R3, R7, dan R8 dibandingkan genotipe lain dan kelima varietas pembanding. Oleh karena itu, GmWMC042*2 tergolong genotipe kedelai yang berumur pendek/genjah $(<80$ hari). Tambaguro 100, dan Tambaguro-E-200 yang keduanya berasal dari Jepang, GmWMC163 yang berasal dari Nepal, dan Pangrango yang berasal dari Indonesia merupakan genotipe yang paling lama mengalami fase R8 (panen). Oleh karena itu, Pangrango, Tambaguro 100, dan Tambaguro-E200 tergolong genotipe kedelai yang berumur dalam ( $>85$ hari). Pangrango mengalami pertumbuhan dan perkembangan yang lama diduga akibat rendahnya viabilitas benih meskipun Pangrango tergolong varietas nasional. Tambaguro 100, dan Tambaguro-E-200 juga mengalami fase pertumbuhan yang lama diduga akibat polongnya yang sangat besar. Hal ini mengindikasikan bahwa pada beberapa genotipe semakin cepat umur berbunga maka akan semakin cepat pula umur panen. Sebaliknya jika semakin lama umur berbunga maka akan semakin lama pula umur panennya. 
Bul. Agrohorti 6 (2) : 258 - 269 (2018)

Tabel 4 Umur tanaman pada saat fase R1, R3, R7, dan R8

\begin{tabular}{|c|c|c|c|c|c|c|c|c|c|}
\hline \multirow{2}{*}{ Genotipe } & \multicolumn{4}{|c|}{ Umur fase (hari) } & \multirow{2}{*}{ Genotipe } & \multicolumn{4}{|c|}{ Umur fase (hari) } \\
\hline & R1 & R3 & R7 & $\mathrm{R} 8$ & & R1 & R3 & R7 & $\mathrm{R} 8$ \\
\hline Tachinagaha & 31 & 35 & 92 & 100 & GmWMC027 & 28 & 36 & 80 & 88 \\
\hline Tanggamus & 43 & 49 & 85 & 94 & GmWMC035 & 28 & 35 & 82 & 90 \\
\hline Anjasmoro & 44 & 50 & 97 & 105 & GmWMC036 & 28 & 35 & 80 & 88 \\
\hline Argo Mulyo & 37 & 42 & 87 & 94 & GmWMC038 & 28 & 35 & 79 & 88 \\
\hline Wilis & 45 & 47 & 88 & 95 & GmWMC042*2 & 28 & 35 & 61 & 66 \\
\hline KOUKOU 6514-2 & 28 & 35 & 95 & 100 & GmWMC046 & 28 & 35 & 83 & 90 \\
\hline Athow & 28 & 35 & 96 & 100 & GmWMC070 & 29 & 35 & 90 & 98 \\
\hline LD003309 & 28 & 35 & 95 & 100 & GmWMC071 & 28 & 35 & 81 & 94 \\
\hline TIEFENG 8 & 28 & 35 & 95 & 100 & GmWMC073 & 28 & 35 & 84 & 88 \\
\hline TIEFENG 18 & 28 & 35 & 95 & 100 & GmWMC084 & 30 & 35 & 80 & 88 \\
\hline THAI-71 AGS 126 & 28 & 42 & 92 & 100 & GmWMC086 & 28 & 35 & 79 & 88 \\
\hline PI416937 & 28 & 41 & 94 & 100 & GmWMC107 & 29 & 35 & 95 & 101 \\
\hline Tambaguro 100 & 33 & 37 & 98 & 112 & GmWMC113 & 28 & 35 & 97 & 101 \\
\hline Tambaguro-E-200 & 33 & 36 & 98 & 112 & GmWMC115 & 28 & 36 & 98 & 102 \\
\hline 317 RINGGIT & 28 & 43 & 72 & 79 & GmWMC119 & 31 & 35 & 88 & 95 \\
\hline SUMBING & 28 & 40 & 72 & 79 & GmWMC123 & 35 & 35 & 79 & 88 \\
\hline GmWMC001 & 28 & 35 & 80 & 88 & GmWMC159 & 31 & 35 & 78 & 88 \\
\hline GmWMC006 & 28 & 35 & 81 & 88 & GmWMC163 & 42 & 50 & 104 & 112 \\
\hline GmWMC015 & 28 & 35 & 79 & 88 & GmWMC173 & 51 & 55 & 87 & 96 \\
\hline GmWMC019 & 28 & 35 & 61 & 66 & GmWMC191 & 52 & 55 & 102 & 110 \\
\hline GmWMC022 & 28 & 36 & 79 & 88 & GmWMC192 & 43 & 48 & 101 & 108 \\
\hline GmWMC024 & 28 & 35 & 79 & 88 & Pangrango & 52 & 52 & 107 & 112 \\
\hline
\end{tabular}

Keterangan: Huruf yang dicetak tebal dalam tabel menandakan genotipe yang memiliki umur paling lama dan paling cepat, dan genotipe yang ditampilkan adalah genotipe yang didiskusikan

Berdasarkan hasil pengamatan bahwa sebagian besar genotipe yang mengalami fase pertumbuhan yang cepat berasal dari wilayah subtropis yaitu Jepang, Korea, Republik Rakyat Cina, dan Amerika Serikat. Hal ini sesuai dengan Sumarno dan Ahmad (2007c) bahwa varietas kedelai dari wilayah subtropis yang sesuai untuk panjang hari 14-16 jam apabila ditanam di Indonesia yang panjang harinya 12 jam maka akan mempercepat pembungaan pada umur 20-22 hari walaupun batang tanaman masih pendek, tanaman sudah berbunga.

Tinggi Tanaman pada Saat Fase Rl dan R7, Jumlah Buku pada saat fase R1 dan R3, Jumlah Cabang, Jumlah Polong, dan Bobot Kering Tajuk

Data hasil pengamatan nilai tengah tinggi tanaman pada saat fase R1, R7, jumlah buku pada saat fase R1 dan R3, jumlah cabang, jumlah polong, dan bobot kering tajuk disajikan pada Tabel 5. Data yang disajikan merupakan genotipe yang memiliki nilai tengah terendah dan tertinggi pada setiap peubah pengamatan dibandingkan kelima varietas pembanding, dan genotipe yang ditampilkan adalah genotipe yang didiskusikan. Pengukuran tinggi tanaman pada fase R1 dan R7 serta perhitungan jumlah buku pada fase R1 dan R3 bertujuan membandingkan hasil peubah pengamatan pada kedua fase tersebut sehingga dapat dilihat tipe pertumbuhan tanaman dari masing-masing genotipe.
Tabel 5 menunjukkan bahwa karakter tinggi tanaman pada saat fase R1 dari genotipe yang diuji berkisar antara 14.10-68.10 cm sedangkan varietas pembanding memiliki nilai tengah antara 30.88-50.84 cm. Berdasarkan uji lanjut BNT, varietas pembanding yang terbaik adalah yang memiliki nilai tengah tertinggi yaitu Wilis sebesar $50.84 \mathrm{~cm}$ sehingga hanya varietas ini yang digunakan sebagai pembanding. GmWMC022 yang berasal dari Korea Utara memiliki nilai tengah yang terendah sebesar 14.10 $\mathrm{cm}$ sehingga menunjukkan bahwa ada perbedaan tinggi tanaman yang nyata lebih rendah dibandingkan Wilis sedangkan GmWMC191 yang berasal dari Filipina memiliki nilai tengah tertinggi sebesar $86.10 \mathrm{~cm}$ tetapi tidak ada perbedaan tinggi tanaman yang nyata dibandingkan Wilis.

Karakter tinggi tanaman pada saat fase R7 dari genotipe yang diuji berkisar antara 14.90-114 $\mathrm{cm}$ sedangkan varietas pembanding memiliki nilai tengah antara 32.38-64.52 cm. Berdasarkan uji lanjut BNT, varietas pembanding yang terbaik adalah yang memiliki nilai tengah tertinggi yaitu Wilis sebesar $50.84 \mathrm{~cm}$ sehingga hanya varietas ini yang digunakan sebagai pembanding GmWMC022 memiliki nilai tengah terendah sebesar $14.90 \mathrm{~cm}$ sehingga menunjukkan bahwa ada perbedaan tinggi tanaman yang nyata lebih rendah dibandingkan Wilis sedangkan GmWMC183 yang berasal dari Taiwan memiliki 
Tabel 5. Nilai tengah tinggi tanaman pada saat fase R1 dan R7, jumlah buku pada saat fase R1 dan R3, jumlah cabang, jumlah polong, dan bobot kering tajuk

\begin{tabular}{lccccccc}
\hline \multicolumn{1}{c}{ Genotipe } & $\begin{array}{c}\text { Tinggi R1 } \\
(\mathrm{cm})\end{array}$ & $\begin{array}{c}\text { Tinggi R7 } \\
(\mathrm{cm})\end{array}$ & $\begin{array}{c}\text { Jumlah } \\
\text { buku R1 }\end{array}$ & $\begin{array}{c}\text { Jumlah } \\
\text { buku R8 }\end{array}$ & $\begin{array}{c}\text { Jumlah } \\
\text { cabang }\end{array}$ & $\begin{array}{c}\text { Jumlah } \\
\text { polong }\end{array}$ & $\begin{array}{c}\text { Bobot kering } \\
\text { tajuk }(\mathrm{g})\end{array}$ \\
\hline Tachinagaha & 30.88 & 32.38 & 9 & 17 & 5 & 33 & 7.14 \\
Tanggamus & 48.28 & 53.52 & 55 & 66 & 9 & 238 & 14.85 \\
Anjasmoro & 46.95 & 48.77 & 24 & 54 & 7 & 96 & 13.39 \\
Argo Mulyo & 39.06 & 52.60 & 24 & 37 & 9 & 118 & 11.91 \\
Wilis & 50.84 & 64.52 & 34 & 65 & 12 & 250 & 14.40 \\
SUMBING & 49.60 & 63.70 & 30 & 46 & $\mathbf{2 3 a}$ & 117 & 7.34 \\
Tambaguro 100 & 22.90 & 30.50 & 15 & 30 & 9 & $\mathbf{7}$ & 13.13 \\
GmWMC001 & 20.20 & 24.70 & $\mathbf{7 b}$ & 11 & 5 & 57 & $\mathbf{1 . 7 7 b}$ \\
GmWMC022 & $\mathbf{1 4 . 1 0 b}$ & $\mathbf{1 4 . 9 0 b}$ & 10 & 15 & 6 & 113 & 3.96 \\
GmWMC107 & 26.00 & 34.10 & $\mathbf{7 b}$ & 10 & 6 & 45 & 12.03 \\
GmWMC108 & 54.30 & 65.60 & 18 & 24 & 7 & 104 & 18.09 \\
GmWMC113 & 27.10 & 54.80 & $\mathbf{7 b}$ & 33 & 7 & 86 & 15.85 \\
GmWMC115 & 23.70 & 24.50 & $\mathbf{7 b}$ & $\mathbf{7 b}$ & 6 & 68 & 7.21 \\
GmWMC123 & 22.90 & 23.30 & 9 & 21 & $\mathbf{3 b}$ & 17 & 2.56 \\
GmWMC129*2 & 30.40 & 32.30 & $\mathbf{7 b}$ & 15 & 5 & 11 & 14.28 \\
GmWMC141 & 49.60 & 51.40 & 46 & 58 & 14 & 91 & 15.31 \\
GmWMC143 & 17.80 & 19.70 & $\mathbf{7 b}$ & 22 & 7 & 50 & 3.75 \\
GmWMC169 & 21.80 & 22.50 & 8 & 10 & $\mathbf{3 b}$ & 61 & 5.84 \\
GmWMC183 & 44.10 & $\mathbf{1 1 4 . 0 0 a}$ & 25 & 116 & 14 & 188 & 14.37 \\
GmWMC191 & $\mathbf{6 8 . 1 0}$ & 107.50 & 53 & 57 & 8 & 235 & $\mathbf{2 4 . 3 0 a}$ \\
GmWMC192 & 43.50 & 55.40 & $\mathbf{8 2}$ & $\mathbf{1 9 0 a}$ & 8 & $\mathbf{4 0 0}$ & 11.40 \\
\hline KK $(\%)$ & 23.71 & 28.37 & 28.12 & 21 & 20.99 & 8.83 & 1.10 \\
\hline
\end{tabular}

Keterangan: $\mathrm{a}=$ Berbeda nyata lebih besar daripada varietas pembanding dan $\mathrm{b}=$ berbeda nyata lebih kecil daripada varietas pembanding berdasarkan Uji BNT pada taraf $\alpha=5 \%$, huruf yang dicetak tebal dalam tabel menandakan genotipe yang memiliki nilai tengah tertinggi dan terendah pada setiap fase, dan genotipe yang ditampilkan adalah genotipe yang didiskusikan.

nilai tengah yang tertinggi sebesar $114 \mathrm{~cm}$ sehingga menunjukkan bahwa ada perbedaan tinggi tanaman yang nyata lebih rendah dibandingkan Wilis. Menurut Adie dan Krisnawati (2007a) perbedaan pertumbuhan vegetatif pada tipe determinit dan indeterminit adalah tipe determinit, pertumbuhan vegetatif akan berhenti setelah berbunga sedangkan tipe indeterminit, pertumbuhan vegetatif akan berlanjut setelah berbunga. Dapat dilihat bahwa GmWMC022 memiliki nilai tengah tinggi tanaman terendah pada fase R1 dan R7 sehingga GmWMC022 tergolong genotipe kedelai yang memiliki tipe pertumbuhan determinit. GmWMC183 mengalami peningkatan nilai tinggi tanaman pada fase R7 yang besar sehingga GmWMC183 tergolong genotipe kedelai yang memiliki tipe pertumbuhan indeterminit. Berdasarkan hasil pengamatan dapat dilihat bahwa GmWMC022 merupakan tanaman yang berumur genjah sedangkan GmWMC191 merupakan tanaman yang berumur dalam. Selain itu, sebagian besar genotipe yang berasal dari
Jepang memiliki nilai tengah tinggi tanaman yang rendah dan berumur genjah. Hal ini mengindikasikan bahwa pada beberapa genotipe semakin rendah tanaman maka fase pertumbuhan akan semakin cepat. Sebaliknya jika semakin tinggi tanaman maka akan semakin lama pula fase pertumbuhannya.

Karakter jumlah buku tanaman pada saat fase R1 dari genotipe yang diuji berkisar antara 782 sedangkan varietas pembanding memiliki nilai tengah antara 9-55. Berdasarkan uji lanjut BNT, varietas pembanding yang terbaik adalah yang memiliki nilai tengah tertinggi yaitu Tanggamus sebesar 55 sehingga hanya varietas ini yang digunakan sebagai pembanding. Dapat dilihat pada Tabel 5 bahwa ada 6 genotipe yaitu GmWMC001, GmWMC107, GmWMC113, GmWMC115, GmWMC129*2, dan GmWMC143 dengan yang memiliki nilai tengah terendah sebesar 7 sehingga menunjukkan bahwa ada perbedaan jumlah buku pada fase R1 yang nyata lebih rendah dibandingkan Tanggamus sedangkan GmWMC192 memiliki nilai tengah tertinggi 
tetapi tidak ada perbedaan jumlah buku pada fase R1 yang nyata dibandingkan Tanggamus.

Karakter jumlah buku tanaman pada saat fase R8 dari genotipe yang diuji berkisar antara 7190 sedangkan varietas pembanding memiliki nilai tengah antara 17-66. Berdasarkan uji lanjut BNT, varietas pembanding yang terbaik adalah yang memiliki nilai tengah tertinggi yaitu Tanggamus sebesar 66 sehingga hanya varietas ini yang digunakan sebagai pembanding. GmWMC115 yang berasal dari Amerika Serikat memiliki nilai tengah terendah sebesar 7 sehingga menunjukkan bahwa ada perbedaan jumlah buku tanaman pada fase R8 yang nyata lebih rendah dibandingkan Wilis sedangkan GmWMC192 yang berasal dari Nepal memiliki nilai tengah yang tertinggi sebesar 190 sehingga ada perbedaan jumlah buku tanaman pada fase R8 yang nyata lebih tinggi dibandingkan Wilis. Berdasarkan hasil pengamatan bahwa GmWMC115 tidak mengalami pertambahan jumlah buku tanaman sampai fase R8 sedangkan GmWMC192 mengalami pertambahan jumlah buku tanaman yang besar sampai fase R8. Menurut Adie dan Krisnawati (2007b) perbedaan jumlah buku setelah berbunga pada tipe determinit dan tipe indeterminit adalah tipe determinit, jumlah buku tanaman setelah berbunga tidak mengalami pertambahan sedangkan tipe indeterminit, jumlah buku tanaman setelah berbunga mengalami pertambahan. Oleh karena itu, GmWMC115 tergolong tipe pertumbuhan determinit dan GmWMC192 tergolong tipe pertumbuhan indeterminit.

Karakter jumlah cabang dari genotipe yang diuji berkisar antara 3-23 cabang. sedangkan varietas pembanding memiliki nilai tengah antara 5-12 cabang. Berdasarkan uji lanjut BNT, varietas pembanding yang terbaik adalah yang memiliki nilai tengah tertinggi yaitu Wilis sebesar 12 cabang sehingga hanya varietas ini yang digunakan sebagai pembanding. Tabel 12 menunjukkan bahwa terdapat 2 genotipe yaitu GmWMC123*2 dan GmWMC169 yang berasal dari Nepal dan RRC memiliki nilai tengah terendah sebesar 3 cabang sehingga menunjukkan bahwa ada perbedaan jumlah cabang yang nyata lebih rendah dibandingkan Wilis sedangkan SUMBING yang berasal dari Indonesia memiliki nilai tengah tertinggi sebesar 23 cabang. Hal ini menunjukkan bahwa ada perbedaan jumlah cabang yang nyata lebih tinggi dibandingkan Wilis. Menurut Yono D (2008) jumlah cabang berkorelasi positif terhadap hasil kedelai dan dipengaruhi oleh intensitas cahaya yang diperoleh tanaman. Semakin tinggi jumlah cabang kedelai maka akan semakin tinggi hasil kedelai yang diperoleh, dan jumlah cabang akan semakin berkurang dengan menurunnya intensitas cahaya. Selain itu, menurut Hakim (2012a) genotipe kedelai yang bercabang banyak cenderung memiliki jumlah polong lebih banyak dan bobot brangkasan lebih tinggi. Oleh karena itu, genotipe SUMBING tergolong genotipe yang memiliki daya hasil lebih tinggi dibandingkan kelima varietas pembanding tersebut jika dilihat dari jumlah cabang yang sangat banyak.

Karakter jumlah polong pertanaman dari genotipe yang diuji berkisar antara 7-400 sedangkan varietas pembanding memiliki nilai tengah antara 33-250. Berdasarkan uji lanjut BNT, varietas pembanding yang terbaik adalah yang memiliki nilai tengah tertinggi yaitu Wilis sebesar 250 sehingga hanya varietas ini yang digunakan sebagai pembanding. Tabel 5 menunjukkan bahwa Tambaguro 100 yang berasal dari Jepang memiliki nilai tengah jumlah polong per tanaman terendah sebesar 7 tetapi tidak ada perbedaan jumlah polong per tanaman yang nyata lebih rendah dibandingkan Wilis sedangkan GmWMC192 memiliki nilai tengah jumlah polong per tanaman tertinggi sebesar 400 tetapi tidak ada perbedaan jumlah polong per tanaman yang nyata dibandingkan Wilis. Berdasarkan hasil pengamatan dapat dilihat bahwa GmWMC192 merupakan genotipe yang memiliki jumlah buku paling banyak pada saat fase R1 dan R8. Hal ini sesuai dengan penelitian Hakim (2012b) bahwa varietas kedelai yang mempunyai jumlah buku subur yang banyak cenderung mempunyai jumlah polong yang tinggi, dan jumlah polong per tanaman berkorelasi positif sangat nyata dengan bobot biji per tanaman.

Karakter bobot kering tajuk dari genotipe yang diuji berkisar antara 1.77-24.30 gram sedangkan varietas pembanding memiliki nilai tengah antara 7.14-14.85 gram. Berdasarkan uji lanjut BNT, varietas pembanding yang terbaik adalah yang memiliki nilai tengah tertinggi yaitu Tanggamus sebesar 14.85 gram sehingga hanya varietas ini yang digunakan sebagai pembanding. Tabel 5 menunjukkan bahwa GmWMC001 memiliki nilai tengah bobot kering tajuk terendah sebesar 1.77 gram sehingga menunjukkan bahwa ada perbedaan bobot kering tajuk yang nyata lebih rendah dibandingkan Tanggamus sedangkan GmWMC191 memiliki nilai tengah bobot kering tajuk tertinggi sebesar 24.30 gram. Hal ini menunjukkan bahwa ada perbedaan bobot kering tajuk yang nyata lebih tinggi dibandingkan Tanggamus. Berdasarkan hasil pengamatan dapat dilihat bahwa GmWMC191 memiliki nilai tengah tinggi tanaman, jumlah buku, dan jumlah cabang 
yang paling tinggi sehingga karakter tersebut yang mempengaruhi nilai tengah bobot kering tajuk GmWMC191 paling tinggi dibandingkan genotipe lainnya. Hal ini sesuai dengan penelitian Hakim (2012c) bahwa varietas kedelai yang batangnya tinggi cenderung mempunyai jumlah cabang, jumlah buku subur, dan jumlah polong per tanaman yang lebih banyak dan bobot brangkasan lebih tinggi daripada varietas yang berbatang pendek.

\section{Bobot 100 Biji, Ukuran Biji dan Warna Biji}

Berikut data bobot 100 biji, ukuran biji, dan warna biji yang disajikan pada Tabel 6. Data yang disajikan merupakan genotipe yang memiliki nilai tengah terendah dan tertinggi dibandingkan kelima varietas pembanding, dan genotipe yang ditampilkan adalah genotipe yang didiskusikan

.Tabel 6. Nilai tengah bobot 100 biji, ukuran biji dan warna biji

\begin{tabular}{|c|c|c|c|c|c|c|c|}
\hline $\begin{array}{c}\text { Varietas } \\
\text { pembanding }\end{array}$ & $\begin{array}{l}\text { Bobot } \\
100 \text { biji } \\
(\mathrm{g})\end{array}$ & $\begin{array}{l}\text { Ukuran } \\
\text { biji }\end{array}$ & Warna & Genotipe yang diuji & $\begin{array}{c}\text { Bobot } \\
100 \\
\text { biji }(g)\end{array}$ & $\begin{array}{l}\text { Ukuran } \\
\text { biji }\end{array}$ & Warna \\
\hline Tachinagaha & 24.10 & Besar & Kuning & GmWMC042*2 & $6.70 b$ & Kecil & Kuning \\
\hline Tanggamus & 13.15 & Sedang & Kuning & Tambaguro-E-200 & $50.53 a$ & Besar & Hitam \\
\hline Anjasmoro & 16.88 & Besar & Kuning & & & & \\
\hline Argo Mulyo & 17.90 & Besar & Kuning & & & & \\
\hline Wilis & 11.81 & Sedang & Kuning & & & & \\
\hline $\begin{array}{l}\text { yar } \\
\text { yar }\end{array}$ & $\begin{array}{l}\text { nilai t } \\
\text { kan. }\end{array}$ & terting & terend & $\begin{array}{l}\text { nbanding dan } \mathrm{b}=\text { bet } \\
\% \text {, huruf yang dicetak } \\
\text { da setiap fase, dan ge }\end{array}$ & yang & $\begin{array}{l}\text { kecil d } \\
1 \text { mena } \\
\text { apilkan }\end{array}$ & $\begin{array}{l}\text { la varietas } \\
\text { n genotipe } \\
\text { h genotipe }\end{array}$ \\
\hline
\end{tabular}

Tabel 6 menunjukkan bahwa karakter bobot 100 biji dari genotipe yang diuji berkisar antara 6.70-50.53 gram sedangkan varietas pembanding memiliki nilai tengah antara 11.81-24.10 gram. Berdasarkan uji lanjut BNT, varietas pembanding yang terbaik adalah yang memiliki nilai tengah tertinggi yaitu Tachinagaha sebesar 24.10 gram sehingga hanya varietas ini yang digunakan sebagai pembanding. GmWMC042*2 yang berasal dari RRC memiliki nilai tengah bobot 100 biji terendah sebesar 6.70 gram sehingga menunjukkan ada perbedaan bobot biji yang nyata lebih rendah dibandingkan Tachinagaha sedangkan Tambaguro-E-200 yang berasal dari Jepang memiliki nilai tengah bobot 100 biji yang tertinggi sebesar 50.53 gram. Hal ini menunjukkan bahwa ada perbedaan bobot biji yang nyata lebih tinggi dibandingkan Tachinagaha. Berdasarkan hasil pengamatan dapat dilihat bahwa kedelai yang berasal dari Jepang tergolong kedelai yang berukuran besar dan sebagian besar genotipe kedelai pada penelitian ini tergolong kedelai yang berukuran besar. Tambaguro-E 200 dan Tambaguro 100 merupakan dua genotipe dari Jepang yang memiliki nilai tengah bobot 100 biji dan umur panen yang tertinggi sedangkan GmWMC042*2 memiliki nilai tengah bobot 100 biji dan umur panen yang terendah. Hal ini mengindikasikan bahwa bobot 100 biji juga bepengaruh terhadap umur panen, semakin tinggi bobot 100 biji maka umur panen akan semakin lama. Sebaliknya semakin rendah bobot 100 biji maka umur panen akan semakin cepat. Berdasarkan data hasil pengamatan dapat dilihat bahwa warna biji tidak berpengaruh terhadap bobot 100 biji dan ukuran biji. Selain itu, sebagian besar pada percobaan ini menggunakan kedelai berwarna kuning.

\section{Persentase Kondisi Biji}

Persentase kondisi biji dihitung dengan mengelompokkan biji berdasarkan kondisinya yaitu biji penuh, keriput, rusak, dan unfertile sesuai dengan kriteria yang ditentukan. Data persentase kondisi benih disajikan pada Tabel 7 . Data yang disajikan merupakan genotipe yang memiliki nilai tengah tertinggi dan terendah dibandingkan kelima varietas pembanding, dan genotipe yang ditampilkan adalah genotipe yang didiskusikan.

Tabel 7 Nilai tengah persentase biji penuh, keriput, rusak, dan unfertile

\begin{tabular}{lcrrrrrrrr}
\hline \multicolumn{1}{c}{$\begin{array}{c}\text { Varietas } \\
\text { pembanding }\end{array}$} & $\begin{array}{c}\text { Penuh } \\
(\%)\end{array}$ & $\begin{array}{c}\text { Keriput } \\
(\%)\end{array}$ & $\begin{array}{c}\text { Rusak } \\
(\%)\end{array}$ & $\begin{array}{c}\text { Unfertile } \\
(\%)\end{array}$ & $\begin{array}{c}\text { Genotipe yang } \\
\text { diuji }\end{array}$ & $\begin{array}{c}\text { Penuh } \\
(\%)\end{array}$ & $\begin{array}{r}\text { Keriput } \\
(\%)\end{array}$ & $\begin{array}{c}\text { Rusak } \\
(\%)\end{array}$ & $\begin{array}{c}\text { Unfertile } \\
(\%)\end{array}$ \\
\hline Tachinagaha & 35.39 & 22.60 & 23.60 & 2.42 & Tambaguro-E-200 & $\mathbf{0}$ & $\mathbf{3 6 . 3 6}$ & $\mathbf{5 4 . 5 4}$ & $\mathbf{9 . 0 9}$ \\
Tanggamus & 85.94 & 1.43 & 12.22 & 0.39 & GmWMC192 & $\mathbf{9 9 . 4 1}$ & $\mathbf{0}$ & $\mathbf{0 . 5 9}$ & $\mathbf{0}$ \\
Anjasmoro & 32.73 & 7.32 & 21.80 & 1.36 & & & & \\
Argo Mulyo & 80.55 & 0 & 16.57 & 2.87 & & & & \\
Wilis & 84.27 & 0.02 & 15.16 & 0.55 & & & & \\
\hline
\end{tabular}

Keterangan: Huruf yang dicetak tebal dalam tabel menandakan genotipe yang memiliki nilai tengah tertinggi dan terendah dibandingkan kelima varietas pembanding, genotipe yang ditampilkan adalah genotipe yang didiskusikan. 
Berdasarkan persentase kondisi biji pada Tabel 7 dapat dilihat bahwa genotipe dengan kondisi biji terbaik adalah genotipe yang memiliki persentase biji penuh yang tinggi sedangkan persentase biji keriput, rusak, dan unfertile rendah. Sebaliknya, genotipe dengan kondisi biji terburuk adalah genotipe yang memiliki persentase biji penuh yang rendah sedangkan persentase biji keriput, rusak, dan unfertile tinggi. Tambaguro 100 merupakan genotipe dengan kondisi biji terburuk karena memiliki nilai tengah persentase biji penuh terendah serta persentase biji keriput, rusak, dan unfertile tinggi sedangkan GmWMC192 merupakan genotipe dengan kondisi biji terbaik karena nilai tengah persentase biji penuh tertinggi serta persentase biji keriput, rusak, dan unfertile rendah.

\section{KESIMPULAN}

Genotipe GmWMC192 yang berasal dari Nepal berdaya hasil tinggi dan beradaptasi baik pada lahan Kebun Percobaan IPB Sawah Baru. Hal ini dilihat dari persentase tanaman yang tumbuh dilapangan, tinggi tanaman, jumlah buku, jumlah polong per tanaman, dan persentase biji penuh yang tinggi.

$$
\text { Genotipe GmWMC019 dan }
$$

GmWMC042*2 yang berasal dari Korea Utara dan Republik Rakyat Cina berumur sangat genjah (66 hari) serta beradaptasi baik pada lahan Kebun Percobaan IPB Sawah baru. Kedua genotipe tersebut dapat digunakan sebagai sumber gen dalam perbaikan umur panen kedelai.

\section{UCAPAN TERIMA KASIH}

Terima kasih kami ucapkan kepada Gene Bank, National Institute of Agrobiological Science, Jepang, Balitkabi, Lab of Crop Science Kyoto University, Prof. Dr. Munif Ghulamahdi dan Dr. Trikoesoemaningtyas yang telah memberikan koleksi genotipe benih kedelai.

\section{DAFTAR PUSTAKA}

Adie, M.M., A. Krisnawati. 2007. Biologi Tanaman Kedelai. Di dalam : Sumarno, Suyamto, Adi W, Hermanto, Husni K, editor. Teknik Produksi dan Pengembangan Kedelai. Bogor (ID): Balai Penelitian dan Pengembangan Pertanian. hlm 45-56.
[BAPPENAS] Badan Perencanaan Pembangunan Nasional 2014. Rencana pembangunan jangka menengah nasional (RPJMN) bidang pangan dan pertanian 2015-2019. [Internet]. [diunduh 2014 Sept 18]. Tersedia pada: http://www.bappenas.go.id

[BPS] Badan Pusat Statistik. 2013. Proyeksi penduduk Indonesia menurut kelompok umur dan jenis kelamin tahun 2012-2013. [Internet]. [diunduh 2013 Okt 20]. Tersedia pada: http://www.datastatistikindonesia.com

Hardjowigeno, S. 1995. Ilmu Tanah. Jakarta (ID): Akademika Pressindo.

Hakim, L. 2012. Komponen hasil dan karakter morfologi penentu hasil kedelai. J. Penelitian Pertanian Tanaman Pangan 31(3).

Kartahadimaja, J., E.R. Syuriani, N.A. Hakim. 2013. Pengaruh penyimpanan jangka panjang (long term) terhadap vaibilitas dan vigor empat galur benih inbreed jagung. $J$. Penelitian Pertanian Terapan 13(3):168173.

Rasyad, A., Idwar. 2010. Interaksi genetik x lingkungan dan stabilitas komponen hasil berbagai genotipe kedelai di provinsi Riau. J.Agron.Indonesia 38(1):25-29.

Sumarno, G.M. Ahmad. 2007. Persyaratan tumbuh dan wilayah produksi kedelai di Indonesia. Di dalam : Sumarno, Suyamto, Adi W, Hermanto, Husni K, editor. Teknik Produksi dan Pengembangan Kedelai. Bogor (ID): Balai Penelitian dan Pengembangan Pertanian. hlm 82-83.

Sumarno, Manshuri. 2007. Persyaratan tumbuh dan wilayah produksi kedelai di Indonesia. Di dalam : Sumarno, Suyamto, Adi W, Hermanto, Husni K, editor. Teknik Produksi dan Pengembangan Kedelai. Bogor (ID): Balai Penelitian dan Pengembangan Pertanian. hlm 82-83.

Yono, D. 2008. Evaluasi genotipe kedelai F4 pada kondisi cekaman intensitas cahaya rendah. [skripsi]. Institut Pertanian Bogor. Bogor. 
Bul. Agrohorti 6 (2) : 258 - 269 (2018)

Lampiran 1 Identitas genotipe yang digunakan pada percobaan

\begin{tabular}{|c|c|c|c|c|c|}
\hline No & Genotipe & Asal negara & No & Genotipe & Asal negara \\
\hline 1 & Enrei & Jepang & 45 & GmWMC066 & Korea \\
\hline 2 & Ryuho & Jepang & 46 & GmWMC070 & RRC \\
\hline 3 & KOUKOU 6514-2 & RRC & 47 & GmWMC071 & India \\
\hline 4 & Athow & Amerika Serikat & 48 & GmWMC072 & India \\
\hline 5 & LD003309 & Amerika Serikat & 49 & GmWMC073 & Korea Utara \\
\hline 6 & TIEFENG 8 & $\mathrm{RRC}$ & 50 & GmWMC075 & Korea \\
\hline 7 & TIEFENG 18 & RRC & 51 & GmWMC083 & Korea \\
\hline 8 & Tachinagaha & Jepang & 52 & GmWMC084 & $\mathrm{RRC}$ \\
\hline 9 & TIDAR & Indonesia & 53 & GmWMC086*2 & RRC \\
\hline 10 & Stressland & Amerika Serikat & 54 & GmWMC089 & RRC \\
\hline 11 & THAI-71 AGS 126 & Thailand & 55 & GmWMC094 & Korea \\
\hline 12 & PI416937 & Jepang & 56 & GmWMC103 & $\mathrm{RRC}$ \\
\hline 13 & KOUSHUREI 273 & $\mathrm{RRC}$ & 57 & GmWMC107 & RRC \\
\hline 14 & SUKHO THAI 1 & Thailand & 58 & GmWMC108 & RRC \\
\hline 15 & $\mathrm{SJ} 4$ & Thailand & 59 & GmWMC113 & Indonesia \\
\hline 16 & Hatsusayaka & Jepang & 60 & GmWMC115 & Amerika Serikat \\
\hline 17 & UA4805 & Amerika Serikat & 61 & GmWMC118 & Korea \\
\hline 18 & 317 RINGGIT & Indonesia & 62 & GmWMC119 & $\mathrm{RRC}$ \\
\hline 19 & SUMBING & Indonesia & 63 & GmWMC120 & Nepal \\
\hline 20 & TAMBORA & Indonesia & 64 & GmWMC122 & Korea \\
\hline 21 & $\mathrm{SJ} 1$ & Thailand & 65 & GmWMC123*2 & Nepal \\
\hline 22 & Fukuyutaka & Jepang & 66 & GmWMC125 & Nepal \\
\hline 23 & Tambaguro-E-200 & Jepang & 67 & GmWMC129*2 & RRC \\
\hline 24 & Tambaguro 100 & Jepang & 68 & GmWMC132 & Filipina \\
\hline 25 & GmWMC001 & Swedia & 69 & GmWMC136 & Indonesia \\
\hline 26 & GmWMC006 & Malaysia & 70 & GmWMC138 & Pakistan \\
\hline 27 & GmWMC011 & Korea & 71 & GmWMC141 & Indonesia \\
\hline 28 & GmWMC012 & RRC & 72 & GmWMC142 & Indonesia \\
\hline 29 & GmWMC014 & Korea & 73 & GmWMC143 & India \\
\hline 30 & GmWMC015 & Korea & 74 & GmWMC144 & India \\
\hline 31 & GmWMC018 & $\mathrm{RRC}$ & 75 & GmWMC146 & India \\
\hline 32 & GmWMC019 & Korea Utara & 76 & GmWMC147 & Thailand \\
\hline 33 & GmWMC020 & Taiwan & 77 & GmWMC148 & India \\
\hline 34 & GmWMC022 & Korea Utara & 78 & GmWMC150 & Nepal \\
\hline 35 & GmWMC024 & Korea & 79 & GmWMC151 & Indonesia \\
\hline 36 & GmWMC027*2 & Korea & 80 & GmWMC152 & Nepal \\
\hline 37 & GmWMC029 & Korea Utara & 81 & GmWMC154 & $\mathrm{RRC}$ \\
\hline 38 & GmWMC035 & RRC & 82 & GmWMC156 & Nepal \\
\hline 39 & GmWMC036*2 & RRC & 83 & GmWMC159 & Pakistan \\
\hline 40 & GmWMC038 & RRC & 84 & GmWMC160*2 & Nepal \\
\hline 41 & GmWMC042*2 & $\mathrm{RRC}$ & 85 & GmWMC162 & Thailand \\
\hline 42 & GmWMC045 & Korea & 86 & GmWMC163 & Nepal \\
\hline 43 & GmWMC046 & Filipina & 87 & GmWMC165 & Taiwan \\
\hline 44 & GmWMC048 & Korea & 88 & GmWMC166 & Indonesia \\
\hline
\end{tabular}


Bul. Agrohorti 6 (2) : 258 - 269 (2018)

Lampiran 1 Identitas genotipe yang digunakan pada percobaan (sambungan)

\begin{tabular}{clclll}
\hline No & Genotipe & Asal negara & No & Genotipe & Asal negara \\
\hline 89 & GmWMC168 & India & 110 & Dering 1 & Indonesia (Balitkabi) \\
90 & GmWMC169 & RRC & 111 & Ijen & Indonesia (Balitkabi) \\
91 & GmWMC170 & India & 112 & Gema & Indonesia (Balitkabi) \\
92 & GmWMC171 & Nepal & 113 & PG-57-1 & Indonesia (IPB) \\
93 & GmWMC173 & Taiwan & 114 & SP304 & Indonesia (IPB) \\
94 & GmWMC175 & RRC & 115 & SC-1-8 & Indonesia (IPB) \\
95 & GmWMC176 & Kamboja & 116 & SC-54-4 & Indonesia (IPB) \\
96 & GmWMC181 & Thailand & 117 & SC-38-1 & Indonesia (IPB) \\
97 & GmWMC182 & Indonesia & 118 & M100-29A-42-14 & Indonesia (IPB) \\
98 & GmWMC183 & Taiwan & 119 & M100-33-6-11 & Indonesia (IPB) \\
99 & GmWMC186 & Indonesia & 120 & M100-46-44-6 & Indonesia (IPB) \\
100 & GmWMC187 & Nepal & 121 & M100-47-52-13 & Indonesia (IPB) \\
101 & GmWMC188 & India & 122 & M150-29-44-10 & Indonesia (IPB) \\
102 & GmWMC190 & Thailand & 123 & M150-69-47-2 & Indonesia (IPB) \\
103 & GmWMC191 & Filipina & 124 & M150-7B-41-10 & Indonesia (IPB) \\
104 & GmWMC192 & Nepal & 125 & M150-92-46-4 & Indonesia (IPB) \\
105 & Tanggamus & Indonesia (IPB) & 126 & M200-13-47-7 & Indonesia (IPB) \\
106 & Anjasmoro & Indonesia (IPB) & 127 & M200-37-71-4 & Indonesia (IPB) \\
107 & Argo Mulia & Indonesia (Balitkabi) & 128 & M200-39-64-4 & Indonesia (IPB) \\
108 & Kaba & Indonesia (Balitkabi) & 129 & Wilis & Indonesia (IPB) \\
109 & Sinabung & Indonesia (Balitkabi) & 130 & Pangrango & Indonesia (IPB) \\
\hline
\end{tabular}

